\title{
伊豆下田附近の海蝕段丘地形と隆起汀線（2）
}

\author{
尾原信彥
}

\section{IV 高低測量による海蝕段丘の復蕃}

\section{A 序 論}

前章にて白濱以北では consequent に本行する河流の下刻が著しいために 段丘は切斷せられ，從つて對比が困難である旨を述べた。併し河流間の山脚 上には，海凔段氒の原形面と舊汀線の痕跡のあるのを認め得る。乃で山脚上 を海岸より分水嶺に向ひ高低测量を實施し，其の數值を斨面に投影し又本面 圓に記大したならぼ，比較的完全な段氒の復舊が出來るであらうと考へた次 第である。猶隆起汀線の位置（舊海崖の痕, 又は海础の堆積）は特に綿密に 测定した。

\section{B 方 法}

アネロイド高度計を地形學研究に使用しを例は少くはないであらうが，カ ラブリヤの地形を研究せる H. Lembke の業蹟の如きでさへ $10 \mathrm{~m}$ を單任 にしてわる位である。海岸段丘の㸴究により地款運動を考察せんとする時に は汀線の絕體高度の誤差は少くも $1 \mathrm{~m}$ 以內になすべきである。野外調查に輕 便な測高器械としてはアネロイド高度計であるな゙大氣の日變化は，日中と朝 夕では,アネロイド計に約 $30 \mathrm{~m}$ 程の誤差を記錄させるので，D. Johnsonの 如きは，晴雨計は絕體に海岸段斥調查には使用できないとまで極言し，之に

(7) H. Lembke: Beiträge zur Geomorphologie des Aspromonte. (Kalabrien) Zeitschr. f. Geomorph. Bd. VI (1931) SS. 58-112.

(8) D. W. Johnson: Principles of marine level correlation. Geogr. Review 22 (1932) pp. 294-298. 


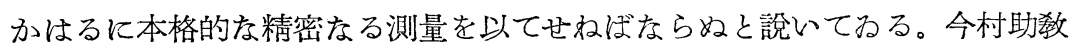
授が紀州の湯崎にて汀線を調查せられた際に，アネロイド計を使用した區域 はアアリダートによる水準測量を施した區域よりも點がぼらついてねる事が明 らかである。

乃で今可の調查では，アネロイド計の讀みの補正には下田臨海實驗所備附 の水銀啨雨計の同時觀测によることにした。同觀测は，筆者が野外にある間

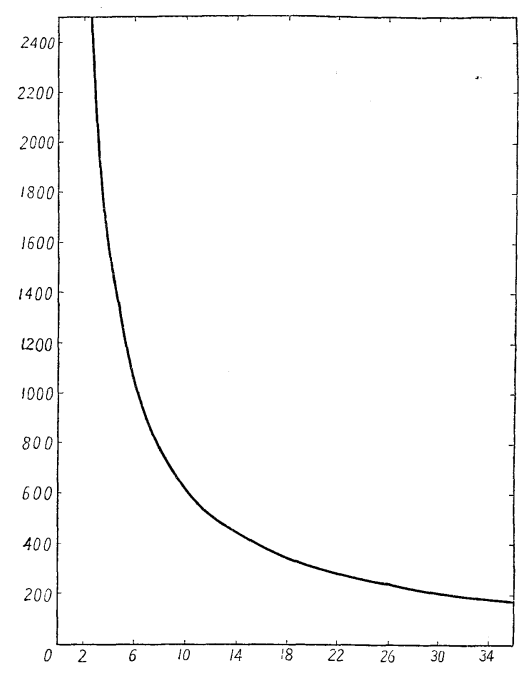

節 5 圖 $6120 \frac{1}{\mathrm{t}}+1,1$
に實驗所にて，略、1時間おうにに箐 丽計水銀柱の高さを讚んだもので， その值に溫度更正不び海面更正を行 ひ，氣壓の日變化を圖式化しておき 野外でアネロイド計を讀多取つを時 刻と對應させ，その時刻における海 面 0 度の氣壓と陸上任意の地點のア ネロイドの值との差から真の高度を 算出した。

水銀啨雨計の更正には,「大正 4 年 度, 氣象觀测法 (中央氣象臺) 」の記 載を臱照した。

$1^{\circ}$ 海面更正數を $\mathrm{C}_{1}$ とすると, 實驗所の晴雨計の海拔高度は $5 \mathrm{~m}$ である から， h=5 なるとき，

$$
\mathrm{C}_{1} \text { の近似值は } \begin{cases}\mathrm{t}=0^{\circ} \rightarrow 10^{\circ} & \mathrm{C}_{1} \fallingdotseq+0.50 \mathrm{~mm} \\ \mathrm{t}=20^{\circ} & \mathrm{C}_{1} \fallingdotseq+0.45 \mathrm{~mm} \\ \mathrm{t}=30^{\circ} & \mathrm{C}_{1} \fallingdotseq+0.40 \mathrm{~mm}\end{cases}
$$

(9) G. Imamura : a. a. O. p-484. 
此値を各時每に加算すればよい。

$2^{\circ}$ 溫度更正數を $\mathrm{C}$ 。とすれば

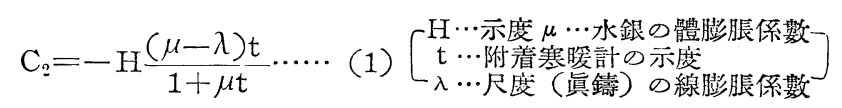

（1）に各常數を代入して變形すると，

$$
\begin{aligned}
& \frac{1}{\mathrm{C}_{2}}=-\left(6120 \frac{1}{\mathrm{t}}+1.11\right)\left(\frac{1}{\mathrm{H}}\right) \cdots \cdots \cdots \cdots \cdots \cdots \\
& \mathrm{C}_{2}=-\frac{\mathrm{H}}{\mathrm{at}-\mathrm{b}+\mathrm{b}} \cdots \cdots[\mathrm{a}=6120 \quad \mathrm{~b}=1.11] \cdots \cdots \\
& \mathrm{C}_{2}=-\frac{\mathrm{H}}{\Delta} \cdots \cdots\left[\cdot\left[=\mathrm{at}^{-1}+\mathrm{b}\right] \cdots \cdots \cdots \cdots \cdots \cdots \cdots\right.
\end{aligned}
$$

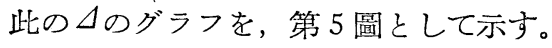

氣壓より高さを出すには，ラプラス公式郎ち

$$
\begin{aligned}
& h=18400\left(\log B_{0}-\log B\right)(1+\alpha t) \cdots \cdots(3)
\end{aligned}
$$

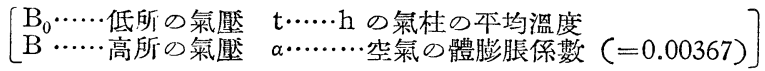

（3）の變數を唯 1 個になすため $(1+a t ）$ を取り去り

$$
\mathrm{h} \fallingdotseq 18400\left(\log \mathrm{B}_{0}-\log \mathrm{B}\right) \cdots \cdots\left(3^{\prime}\right)
$$

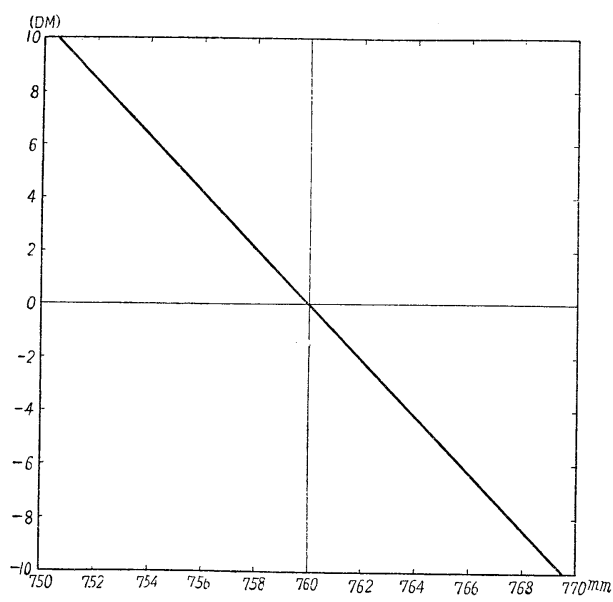

第 6 圆 $\mathrm{y}=18400 \times(2.88081-\log \mathrm{x})$
此時に於ける誤差は， $10^{\circ} \mathrm{C}$ にて $4 \%, 30^{\circ} \mathrm{C}$ に $9,8 \%$ 位で，大凡 1 割以下である。 (3’)のグラフを第 6 圖として 示す。アネロイド計の目盛は （3’）去る承數に極めて近い。 今四の野外調查にては, 氣溫 を計らなかつをが；大部分は 冬季の $10^{\circ} \mathrm{C}$ 內外であつたか ら誤差は僅かである。 

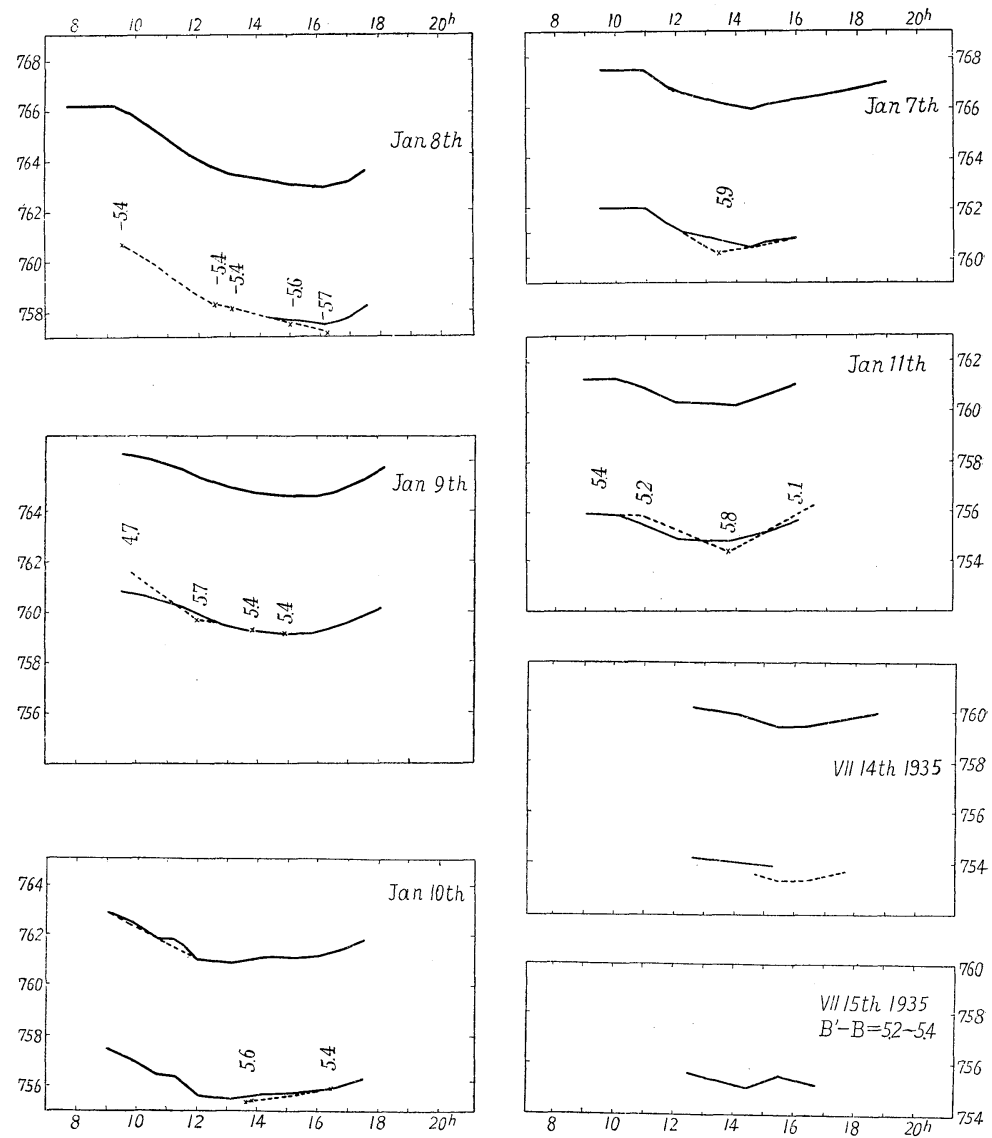

第 7 圆 アネロイド高度計使用日に於ける $\mathrm{B}_{0}^{\prime \prime}$ 及び $\mathrm{BL}$ のグラフ (賽線 Standard 點線 Experimental 整字は h を表はす)

次にアネロイド計読取値の補正處理を示す。

$\mathrm{B}_{0} \cdots \mathrm{P}$ 定點（海拔高度 $h^{\mathrm{m}}$ ) に於ける某時刻の清雨計の示度(附着塞暖計 $t^{\circ} \mathrm{C}$ ) $\mathrm{B}_{0}{ }^{\prime} \cdots \mathrm{P}$ に崩ける $0^{\mathrm{m}}$ (海面) $0^{\circ} \mathrm{C}$ の換算示度

B …司時刻におけるQ地點（Pより比較的隔らない所）にて計つ沉アネロイ ド計の讀取值 
さてQ地點の買の高さ（そ）を出す順序を示せぼ，さきに出した $\mathrm{C}_{1}, \mathrm{C}_{2} に$ より $\mathrm{B}_{0}{ }^{\prime}$ を出す。即古

$$
\mathrm{B}_{0}+\mathrm{C}_{1}+\mathrm{C}_{2}=\mathrm{B}_{0}^{\prime}
$$

第 7 圆は此の $\mathrm{B}_{0}{ }^{\prime}$ 日變化を記入しをもの。次に豫め $\mathrm{k}$ (アネロイド計と晴 雨計との示度差……日により違ふから每日测り直す要あり）を測り置き， $\mathrm{B}_{\jmath}{ }^{\prime}+\mathrm{k}=\mathrm{BL}$ なるグラフを書く。此のグラフ（第7 圖に記大す）は， $\mathrm{B}_{\jmath}{ }^{\prime} の$

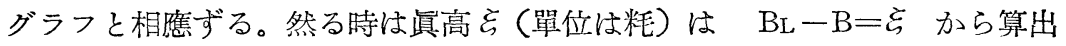
される。郎ち，（3）式 (ラプラス式）に， $\mathrm{B}_{0}=760,00 \mathrm{~mm}$. を代大すると，

$$
\log \mathrm{B}=2.88081-\frac{\mathrm{h}}{18400+68 \mathrm{t}}
$$

（4）に代入して，が出される。

第 1 表は, 本調查の行はれた日の晴雨計の值, 時刻, 附着寒暖計示度を示 した表である。

實驗所に在つて, 水銀晴雨計讀み取りの管を執られた吉村講師, 福井英一 郎氏，橋崎清氏，土屋貞子氏，進士福太郎氏に對し謝意を表する次第である。

\begin{tabular}{|c|c|c|c|c|c|c|c|c|}
\hline \multicolumn{3}{|c|}{ 時刻 $T$ (氣溫) $B$ o(晴雨計) } & 時刻 & $\mathrm{T}$ & Bo & 時刻 & $\mathrm{T}$ & Bo \\
\hline $\begin{array}{c}7 \text { th. Jan } \\
9.30\end{array}$ & $7.5^{\circ \mathrm{C}}$ & 768.4 & $13.00^{\mathrm{h}}$ & $11.0^{\circ}$ & $\underset{766.4}{\mathrm{~mm} .}$ & $16.00^{\mathrm{h}}$ & $13.0^{\circ \mathrm{c}}$ & $\underset{762,7}{\mathrm{~mm} .}$ \\
\hline 10.30 & 8.4 & 768.5 & 14.00 & 11.7 & 767.1 & $\frac{18.25}{14 \text { th. Jul. }}$ & 12.0 & 768.3 \\
\hline 10.53 & 8.3 & 768.5 & 15.20 & 12.0 & 766.1 & 14.10 & 27.4 & 763.36 \\
\hline 12.10 & 9.4 & 767.7 & 16.00 & 12.0 & 766.1 & 15.30 & 28.0 & 763.0 \\
\hline 13.30 & 9.4 & 767.3 & $\frac{18.10}{10 \text { th. } \operatorname{Jan}}$ & 11.1 & 767.1 & 16.20 & 28.3 & 762.96 \\
\hline 14.30 & 9.5 & $767 \cdot 1$ & 9.00 & 10.5 & 764.0 & $\frac{17.30}{15 \text { th. Jul. }}$ & 27.6 & 763.16 \\
\hline 15.00 & 9.0 & 767.2 & 9.50 & 10.6 & 763.8 & 12.30 & 27.5 & 759.1 \\
\hline 16,00 & 9.9 & 767.5 & 10.40 & 11.0 & 763.2 & 13.30 & 27.6 & 758.8 \\
\hline$\frac{19.00}{8 \text { th. Jan. }}$ & 8.6 & 768.0 & 11.10 & 11,0 & 762.9 & 14,30 & 28.9 & 758.71 \\
\hline 7.45 & 5.6 & 766.9 & 12.00 & 11.2 & 762.4 & 15.30 & 27.8 & 759,0 \\
\hline 9.15 & 5.6 & 766.9 & 13.10 & 11.3 & 762.3 & $\frac{16.30}{17 \text { th. Jul. }}$ & 27.5 & 758.7 \\
\hline
\end{tabular}

第 1 表 


\begin{tabular}{|c|c|c|c|c|c|c|c|c|}
\hline 9.45 & 6.9 & 766.8 & 14.05 & 11.3 & 762.5 & 9.30 & 26.6 & 752.5 \\
\hline 10.45 & 8.5 & 766.2 & 15.05 & 11.3 & 762.5 & 10.30 & 26.8 & 752.5 \\
\hline 11.45 & 9.5 & 765.4 & 16.00 & 11.5 & 762.6 & 11.30 & 27.4 & 752.5 \\
\hline 13,10 & 9.6 & 764.7 & 17.30 & 11.4 & 763.2 & 12.30 & 27.5 & 752.3 \\
\hline 14.10 & 9.7 & 764.5 & $\begin{array}{c}11 \text { th. Jan. } \\
9.00\end{array}$ & 10.0 & 762.5 & 13,30 & 27.7 & 752.2 \\
\hline 15.00 & 10.1 & 764.3 & 10,00 & 10.7 & 762.6 & 14.30 & 27.8 & 752.2 \\
\hline 16.00 . & 10.2 & 764.3 & 11.00 & 11.6 & 762.3 & 15,30 & 28,1 & 752.2 \\
\hline 17.45 & 10.3 & 764,9 & 12.00 & 12.7 & 761.9 & 16.30 & 28.0 & 752.3 \\
\hline $\begin{array}{c}9 \text { th. Jan. } \\
9.30\end{array}$ & 7.5 & 767.2 & 13,00 & 12.7 & 761.8 & 17.30 & 28.0 & 752,6 \\
\hline 10.30 & 9,8 & 767.3 & 14.00 & 12.8 & 761.8 & 19.00 & 26.4 & 752.7 \\
\hline 11.30 & 11.0 & 767,0 & 15.00 & 12.9 & 762,2 & & & \\
\hline
\end{tabular}

\section{C アネロイド測量賽施と其效果}

\section{(i) 測量を行へる山脚の個别的概說}

水準测量により段丘の對比を行つた地域は南は外浦一上，山附近より，北 は下河津村大字谷津字葛蒲澤附近迄 6 籸の間で, 此間には前記の山脚が皆で 15一20 ある。第 3 圖に太線を以て示したのが，测量を施した尾根である。此 外, 第 VI 章の地殼運動研究の鸴に, 特に隆起汀線のみを測定した所が, 須 崎斗島, 平石山（繩地山塊）附近にある。猶此分は昭和 10 年 7 月に行つた。

水平距離の測距には, 步測（pacing）飞地形圖（2 莴分 1 ）の位置判斷に より，特に傾科大なる所は尞尺を使用した。賽驗によれぼ步測は傾斜 $20^{\circ}$ 以 下では誤差が著しくない。步測を地形研究に使用した例はある。

次に测量を施行した尾根の一つ一つに就ては簡單な地形其他を記しておく。

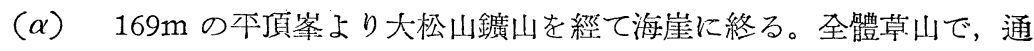
行容易であつた。平頂崟上は土壤を被り本坦面が明嘹, 街道迄猛烈な急崖

(10) Kirk Bryan and Franklin McCann: Successive Pediments and Terraces of the Upper Rio Puerco in New Mexico. The Journal of Geology. Vol. XLIV (1936) $\mathrm{p}-170$. 
(35m) 露岩(安山岩)が著しい。崖下に人頭大の海碟がある(海拔 $130 \mathrm{~m}$ )。此 崖は一つ南の妻坂䟔直上にも又直ぐ北の菖蒲澤にも著しく，殊に後者は（寫 真. 4.) 明膫な海岸段丘の觀を呈す。此處より約 $400 \mathrm{~m}$ 程本坦面が續き，急崖 （50m）を下ると又本坦面となるが，此處には至る所に庱坑の跡がある。崖は 安山岩をけづつたものであつた。又 $400 \mathrm{~m}$ 程緵傾斜地がつがき, $30 \mathrm{~m}$ の崖に て海面に達す。( $\alpha$ ) 山脚は一塊の安山岩より成り, それに上述の舊海崖が武 込まれてねる。

（B） 170-190m の所に急斜面があり, 安山岩が露出し, 此處より $200 \mathrm{~m}$ 程上下しつつ下り, 海拔 $150 \mathrm{~m}$ の邊りょり $20 \mathrm{~m}$ 急降下, 再び火山岩塊の上 を緵に下り, 繩地小學校の所は稍。鞍部をなし, 新道の戓通より急下して後, 同じ高さで海崖に終る(竄真 4)。

繩地山塊（本石山）の周園に幾段もの海蝕段丘が附いてわる。是等は昭和 10 年 7 月に補充测定をした。此の山塊の東突端及び突端に近い南側はその後 の海蝕のために段丘が失はれてるる。

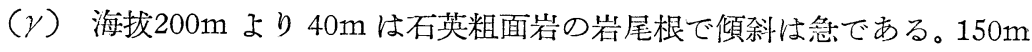
の附近に一寸したべンチがあり，露岩の著しい坂を $30 \mathrm{~m}$ 下ると廣い本尾根 となる。此段は石英粗面岩の堅岩よりなり，上述つ崖は此岩を切达んで偆玲 したものである。五本松の所より一擧に $30 \mathrm{~m}$ 下つて, 平坦面 (海拔 $70 \mathrm{~m}$ ) になり,ここには土壤がのり, 訵地が開ける。板戸の部落の北側に下り, 再 び $25 \mathrm{~m}$ の神社の在る孤丘に上る。この丘は池，段に相當する殘片であらう。

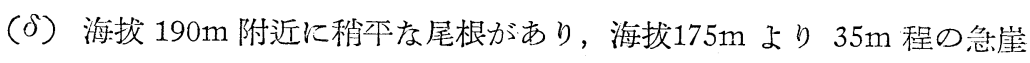
があり, 岩が露出する。海拔 $130 \mathrm{~m}$ 迄の平坦面は烟地となつてるる。 $80 \mathrm{~m}$ 迄斜 面を下ると再び廣い平坦な烟地になり $500 \mathrm{~m}$ 程つづく。海拔 $50 \mathrm{~m}$ より $20 \mathrm{~m}$ 迄崖があつて其直下に板戸聚落がある。此崖は凝灰岩や頁岩層である。 


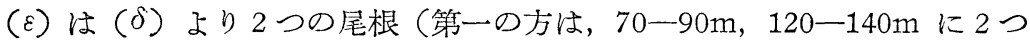
の本面が認められ，第 2 の方は 45-80m，110-130m 邊りに 2 つの面が認 められる)を隔てて南に在る。（ $\varepsilon$ ) は海拔 $190 \mathrm{~m}$ より同 $160 \mathrm{~m}$ 迄緩かな山 稜で，基盤は頁岩である。一度下つて又 $115 \mathrm{~m}$ の圓頂峯があり，其の東斜面 は急崖をなす。 $80 \mathrm{~m}$ の所より又緩かになり漸次白濱小學校のある面となる。 街道の所で一旦下つて砂をかぶる丘となる。この山稜は基盤は水成岩であつ て，この附近が水成岩の露出が最も廣い。表面には風化土層がのつてわる。

(〔） $180 \mathrm{~m}$ 邊りに本坦面があり，140m 迄斜面があり，しばらく本坦面が あつて, $120 \mathrm{~m}$ より約 $40 \mathrm{~m}$ 程下つて本らになる。ここに原田部落の一部が 載る。

（ク）は萬藏山東北の海拔 $200 \mathrm{~m}$ の平坦面より白濱の砂丘迄の山稜である。 最初 $50 \mathrm{~m}$ の急崖を下り $160 \mathrm{~m}$ の平坦面に達し, $30 \mathrm{~m}$ 下つて $120 \mathrm{~m}$ の本坦 面となり，又 $90 \mathrm{~m}$ のベンチには大礫がある。160m の邊りは露岩が著しか つた。

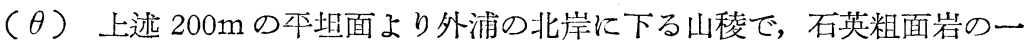
塊を幾段かの侵刢面に分かつ。160m の所に一ヶ所ベンチあり，約 $40 \mathrm{~m}$ の急 崖により直ちに 120一 $100 \mathrm{~m}$ の面に急傾斜す。此面上には畑地が開け，更に 石英粗面岩の露岩を件つた斜面に移行し，舊白溑道の通ずる $80 \mathrm{~m}$ の平坦面 となる。ここに圓礫が堆積してるる。この面（俚稱女郎畑）は畑地となり上 ，山一外浦の谷を陪てて須崎牛島の平坦面に呼應する。

\section{（ii） 測量の結果の斷面投影}

各尾根(山稜)の水準測量の結果數值を第 2 表に例示す。最初の行に位置を 記入し，海岸よりの距離で示し，第 2 行にはアネロイドを讀んだ時刻，第 3

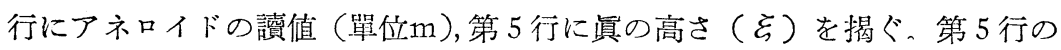




\section{第 2 表}

高低測量實施例 ( $\theta$ 山稜 7 例示ス) 11 th. Jan. 1935

\begin{tabular}{|c|c|c|c|c|c|c|c|c|c|c|c|}
\hline $\begin{array}{c}\text { 海崖ヨリ } \\
\text { 距離 }\end{array}$ & 時 刻 & 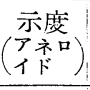 & 更正值 & & 備栲 & 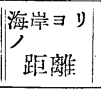 & 時刻 & 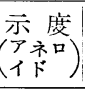 & 更正值 & 實 高 & 備 考 \\
\hline $\begin{array}{ll}\mathrm{m} & 0\end{array}$ & 16.35 & 41 & -41 & & 0 & $\mid \mathrm{m} 1100$ & 14.47 & 129 & -52 & & 7第 2 汀線 \\
\hline 33 & 16.31 & 64 & -41 & & 3 第 1 汀線 & 1166 & 14.52 & 141 & -52 & 89 & \\
\hline 66 & 16,27 & 81 & -41 & 40 & 0 & 1223 & 14.55 & 150 & -52 & 98 & \\
\hline 100 & 16.24 & 89 & -42 & 47 & 7 & 1300 & 14.57 & 157 & -51 & 106 & \\
\hline 166 & 16.21 & 97 & -42 & 48 & 8 & 1366 & 15.03 & 160 & -49 & 111 & \\
\hline 200 & & 91 & -42 & 45 & 9 & 1423 & - & 158 & -49 & 109 & \\
\hline 300 & 16.05 & 90 & -43 & 47 & 7 & 1500 & 15.07 & 160 & -49 & 111 & \\
\hline 366 & & 104 & -43 & 61 & 1 & 1623 & 13.55 & 168 & -58 & 110 & \\
\hline 423 & 16.01 & 103 & -43 & 60 & 0 & 1700 & 13.51 & 173 & -58 & 115 & \\
\hline 500 & 16.00 & 108 & -43 & 65 & 5 & 1766 & - & 172 & -59 & 113 & \\
\hline 566 & 15.55 & 110 & -44 & 66 & 6 & 1823 & 13.18 & 175 & -57 & 118 & \\
\hline 623 & 15.52 & 121 & -44 & 77 & 7 & 1900 & 13.13 & 187 & -57 & $130^{\circ}$ & \\
\hline 700 & 15.34 & 124 & -46 & 78 & 8 & 1966 & 13.07 & 203 & -56 & 147 & \\
\hline 766 & 15.30 & 123 & -46 & 77 & 7 & 2023 & - & 224 & -55 & 170 & \\
\hline 823 & 15.26 & 123 & -47 & $7 \epsilon$ & 6 & 2100 & 12.51 & 224 & -55 & 170 & \\
\hline 900 & 15.23 & 118 & -47 & 71 & 1 & 2166 & 12.44 & 220 & -54 & 166 & \\
\hline 966 & 15.20 & 116 & -48 & 68 & 8 & 2223 & 12.37 & 232 & -53 & 179 & \\
\hline 1025 & 15.17 & 121 & -48 & & 3 & 2300 & 12.34 & 238 & -53 & 185 & \\
\hline
\end{tabular}

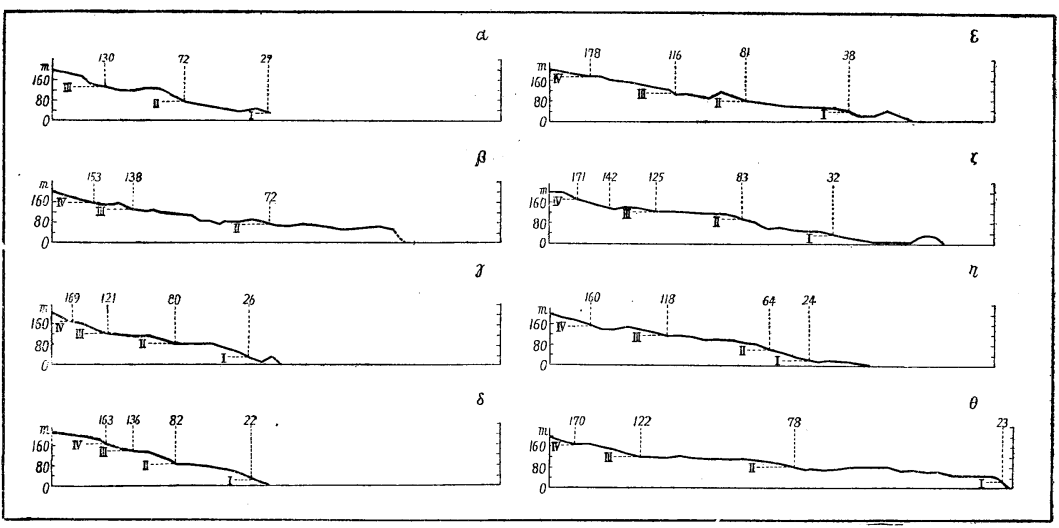

第 8 圖 海岸段斥プロファイルと汀線位圆 
數值を斷面に直して, 第 8 圖を得た。垂直距離は水平距離の約 1.25 倍に當 る。縱軸にそを, 橫軸に海岸よりの距離(m)を取つた。猶此の圖には傾斜の 變換點に於て，……線を以て本坦面と崖との交りを示した。

第 2 の段丘の隆起汀線は大抵の山脚に共通しておる。此の平坦面は比較的 完全に保存せられ，畑地と存るふ又は聚落を載せてるる。第 3 の汀線は 120 $\mathrm{m}$ 前後に來るが, 場所による異同がある。この第 3 面も畑地となる場合が多 い。第 4 の面は幅が狹く明瞭でなく，場所により高さの差がある。郎ち此の 海蝕面は第 1 ，第 2 ，第 3 段の上に來るから，垂直的位置は是等の地殼運動 の總和として與へられ，從つて場所的垂直偏差が援大する。竄真 3 にある如 く舊白濱街道の拤（萬藏山の裹）に當る所では, 此段丘は互ひに逆傾斜を爲 す事は注目に值する。

最下部（第 1 , 師「池，段」）の段丘は須崎牛島の南部に明瞭に發達する。 併し, 外浦一長田間, 板戶一色附近に認められ，別に又田牛附近にも明潦な ものがある。

\section{（iii） 測量結果の平面投影}

上述の测量值（第 2 表そ）を本面圖に記大して山脚と山脚の間の谷を埋め て段丘面を復舊し, 测量を殆ぞ行はなかつた須崎坐島以西は觀察をさとして， 地形圖( 2 萬分 1 )より切峯面を作り，便宜上此兩者を絬んで第 9 圖を得を。

最北部の大松山妻坂趾近傍では第 $2(40-75 \mathrm{~m})$ と第 $3(100-130 \mathrm{~m})$ 段丘 とが良好な發達を示す。緧地村では第 2 段丘が奥地に侵大し, 廣さも大き W。第 3 段丘の存在も指摘できる。板戶一色方面では第 2 段 $(50-80 \mathrm{~m})$ は 稍傾科が大きく第 3 段（100-130m）は割に緩な科面である。第 4 段丘は峠 及び本石山東部にある。但し本石山東部のは $200 \mathrm{~m}$ に來るであらう面との區 別が困難である。板戸の背後では幅が狄い。第 1 段も幅が狹い。白濱(原田・ 


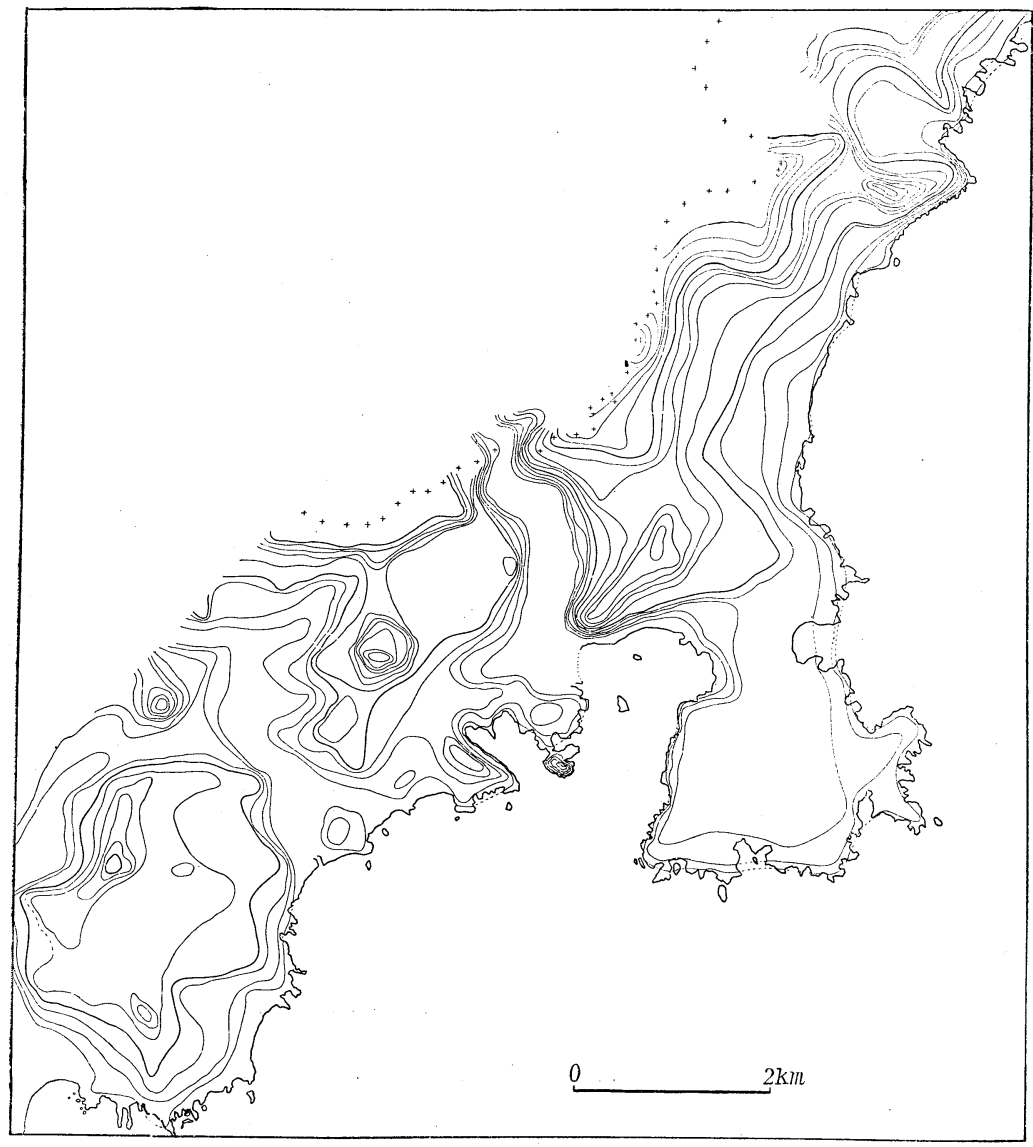

第9圖 段 丘復 舊 圖

長田）では第 2 と第 3 段丘とが明らかである。前者は原田・長田双方に，後 者は長田に良く發達する。兩面の垂直的距離は $40 \mathrm{~m}$ 位である。第 4 段の面 恪急傾して狹く，140-160m の所にある。上，山東部では第 2 と第 3 段丘の 境界が分かるし，萬藏山塊の石英粗面岩を侵蝕した第 4 段丘も分かる。此の 山塊の北部郎ち下田より白濱に出る裏道の䟔は第 4 段丘面を通過するが案外 
廣い面である。无も實際は舀真 3 の如く, この面は侵蝕せられ，谷に對して 互に逆傾斜をなす。

須崎斗島上の第 2 段丘面は平坦度・面積共に大である。傾科の方向は東南 東で，最初全く本坦であるが，池，段（第1段丘）に近接するにつれ漸次傾 科を增す。下田町の西及び南には第 2 段丘が發澾よく西北部には第 3 の面が 發達し此の兩者は相，山の麓を取卷いてるる。吉佐美の西南部にも本坦面が 指摘できる。

\section{(iv） 4 段の海岸段丘の確認}

以上述へ來た事を總括するならば，伊豆東南部の下田白演附近には，海蝕 段丘が 4 段あり，何れも夫ふ一定の高距を以て順次に重疊し，過去に於ける 土地の週期的上昇運動を示す。之が高距並びに海拔高度は次の如し。

$$
\begin{array}{cll}
\text { 段丘 iv } & 50 \mathrm{~m} \pm\left(\Delta_{1}+\Delta_{2}+\Delta_{3}+\Delta_{4}\right) & 160 \mathrm{~m} \pm\left(\Delta_{1}+\Delta_{2}+\Delta_{2}+\Delta_{3}\right) \\
\text { iii } & 30 \mathrm{~m} \pm\left(\Delta_{1}+\Delta_{2}+\Delta_{3}\right) & 110 \mathrm{~m} \pm\left(\Delta_{1}+\Delta_{2}+\Delta_{2}\right) \\
\text { ii } & 50 \mathrm{~m} \pm\left(\Delta_{1}+\Delta_{2}\right) & 80 \mathrm{~m} \pm\left(\Delta_{1}+\Delta_{2}\right) \\
\text { i } & 30 \mathrm{~m} \pm \Delta_{1} & 30 \mathrm{~m} \pm \Delta_{1}
\end{array}
$$

$\Delta_{1} \Delta_{2} \cdots \cdots \cdot$ は局部的の地殼運動量を示し，次そ章に詳說する。

上記の 4 段丘は何れも次章に述べる如く，地質構造と涠關係に海波により 破壞侵蝕せられた面及び汀線を殘す。爾後の河蝕・海蝕などにより段丘が失 はれ，又は不分明にされた所もあるが，原則的には上記 4 度の海面に對する 相對的運動を歸納し得たのは前記水準测量の效果である。猶地形圖より本坦 面を拾ひ出せぼ第 4 圖の如くになる。其分布の狀態より言ふならぼ，第 2 段 丘が完全に連なり，第 3 段丘は之に次ぐ。第 4 段丘は場所により失はれ，幅 も狹い。第 1 段丘は田牛池，段に良好な保存ある外は概して不明瞭で（外浦 一板戸）あり，とくに下田灣內及び一色以北には見當らない。恐らく，此段 
丘形成後, 部分的に沈降が行はれて溺谷を生じを所や海蝕の著しかつた所で は消失したのであらう。

\section{V. 隆起汀線附近に生ずる Subsequent 谷の 侵蝕による段丘の開析と盆地の生成}

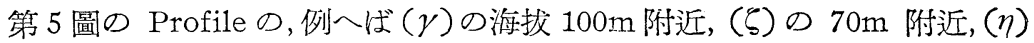
の $155 \mathrm{~m}$ 附近, $(\theta)$ の $160 \mathrm{~m}, 120 \mathrm{~m}$ 附近は, 海岸寄りが高く, 海に向つて逆傾 斜し汀線の所から再び正傾斜の崖となる。之は現地を步めば直に氣附く事で， 最低所は風化土壤がとれて基岩が露出する事がある。此處では山脚の幅も樉 まり，平坦面の面積も縮少する。平面圖に模式化するならば，段丘面は最低 所をる鞍部を要として海岸に向ひ㱆げられた屣の形を呈す。

此の現象は次の如く解釋する事が出來る。海蝕段丘が完全な間は此原形面 を刻む谷はなく，階段狀を示す。第 4 章 $3^{\circ}$ (345 頁)に記した樣に游蝕段丘は 傾斜が奧程緩かで, 先端程急であるから, 最前端に先づ consequent の谷が刻 まれ，漸次頭部侵蝕をなしつつ後退するから，前端には急速に深い谷が構成 される。しかし後退するにつれ，流路は高度差を減ずるから頭部侵蝕の速度 は停滯し，一直線に進む代りに，侵搶の頭部たる替鉢狀小盆地はかへつて擴 つて行く。他方隆起汀線（傾斜變換點）附近には何等かの契機により，汀線 と同方向の谷の素地がつくられ易い。郎ち崖の直下であるから崖上より流下 する水量が多いとか，又は泉源が崖下に連續するといふ事が原因となり，時 間的に早く崖下の地を風化する。此の subsequent の風化土壤地帶と頭部侵 玲盈地とが連結する事により，一層此河谷の發達が助長せられ，侵蝕は逐次 山脚を破壞し始め, 原形面は陝をる。もし相隣る 2 つの谷頭の侵玲が接觸す るならば，原形面は崩されて瘦尾根となり，Profile は海に對して逆傾斜と 


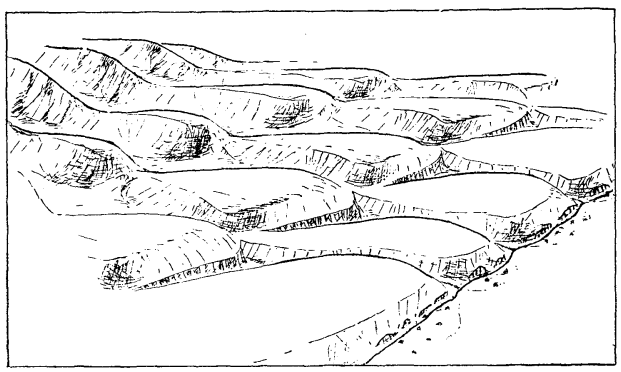

第 10 圆 海:岸段丘に生ずる谷系
なる。段丘前端に生じを最初 の谷は横に發展することなく 下刻するだけで峽谷の觀を呈 するから，そこには原形面は 最子廣く殘され，谷の出口の 所だけ少し侵蝕されて，原形 面の前崖は弧跃となり凸部を

海岸に向ける。(第 10 圖を見よ)

此地形は白濱一色間に著しく, 就中幅廣き第 2 段丘に好例を見る。縣道の 直上前崖の上は原形面たる畑地が開けるが，山に向つて漸次幅を炏的，尾根 は逆に傾き, 隆起汀線附近で正傾斜となる。最前端は横の狭い溪谷を隔てて 隣の面に連なるから，ここで段丘の現地觀察による對比を行へば誤が少い。 最奧の鞍部に來ると兩侧の川谷は廣けて盆地となり，盈地壁は階段爿の耕地 に利用される位綾やかになる。板戸部落南隣の尾根の如きは最好例である。 此處より長田部落の載る面迄，3つの山稜には，3 段の段丘の汀線に相應す

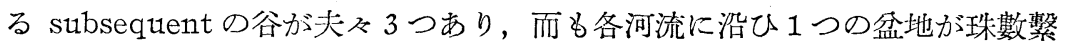
ぎに列ぶ。魪最も上流の盆地を考へれば４つになる。原田附近の一番下の段 では subsequentの谷の方が主谷よりる發澾し, 時には尾根を横斷する事さ 一ある。併し，第 2 段以上は大體長田・板戸間の如き盆地列である。

$(\theta)(\eta)$ の尾根にも此の鞍部が存在し，第 3 段が一番明らかである。上， 山より外浦に注ぐ河流も此種の consequent 谷の連續であつて, 出口附近は 峽谷狀をなすが，其奧には盆地が開け，其處には上，山の聚落が占據し，更 に上の盆地は貯水池となる。其他下田町字横枕，字鍋田の奥にも，相，山の 南麓吉佐美村字寒畑に \&第 2 段丘汀線附近に此の盈地があり, 又相，山西麓 
には第 3 段を第つた大きな盆地がある。朝日村大字田牛の南方の段丘の西南 部にも此種の立派な例がある。

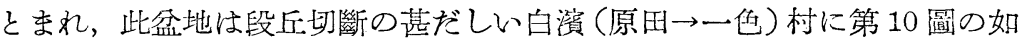
く標式的に發澾し, 而名此地域には數も多い。一河系中に存する此種盆地の 數は，其河系を橫断する隆起汀線の數に對應するものらしい。

Subsequent 谷の形態のみから分類すれぼ，

$1^{\circ}$ 鍋田・裹畑・上，山等にある如き subsequent 谷の發達惡きもの。

$2^{\circ}$ 田牛, 相, 山西麓, 橫枕, 板戶, 長田に見る樣な subsequent 谷が流域 內一杯に發達する正常なるの。

$3^{\circ}$ 原田に於て見る如き subsequent 谷の發達が，隣接する主谷の侵蝕より

優り，分水山脚を切下げて, piracy を起すに至つたもの。

以上の如く，形態的に 3 つに分類せられるが， $3^{\circ}$ の如きは，沈降運動の影 響もあり，又岩質，水量，傾斜などにも左右されるから，此の分類は絕對的 のものとは言ひ得度い。

\section{VI 隆起汀線に依り定量せられた南伊豆地方の地殼運動}

前及章に於て述べた 4 段の海蝕段丘によつて此の地方に行はれた地殼運動 を测定しょう。前に言つた樣に，此處の段丘は其成生後河蝕により至る所で 切斷され，唯河流の侵蝕より最も遠ざかつてょる山脚の部分に原形が保存さ れてわるので, 切れ切れになつてねる段丘を連續せしめれば，一續きの段丘 の帶が得られ，其れにより地殼運動を推定する事が出來る。而して之が連結 の方法には，平坦面の平均高度を點描して行くものと，平坦面の最も奧にあ たる舊汀線の高度を點描して行く方法等があり，何れにしても凡そ相似を結 果が得られようが今包は舊汀線の位置が各山脚の上に得られ，其の海拔高度 
第 3 表

17 th. July. 1935

\begin{tabular}{|c|c|c|c|c|c|c|}
\hline 場 所 & 時 刻 & $\mathrm{B}_{0}$ & $\begin{array}{c}\text { 示 度 } \\
\text { (ラネロイ゚) }\end{array}$ & $\mathrm{Br}$ & $\mathrm{Br}_{\mathrm{s}}-\mathrm{B}$ & $\xi$ \\
\hline$\lambda_{13}$ & $\begin{array}{r}\mathrm{h} \\
9.50\end{array}$ & $\operatorname{m.m}_{751.0}$ & ${ }_{98}^{\mathrm{m}}$ & $\underset{753.63}{\text { m.m. }}$ & $\underset{2.63}{\mathrm{~m} . \mathrm{m}}$ & $\begin{array}{c}\mathrm{m} . \\
28.0\end{array}$ \\
\hline$\eta_{9}$ & & 745.9 & 150 & 753,62 & 7.72 & 81.5 \\
\hline$\mu_{9}$ & 11.20 & 742.6 & 254 & 753.63 & 11.03 & 116.8 \\
\hline$\mu_{10}$ & 13.10 & 742.6 & 161 & 753,30 & 10.70 & 113.1 \\
\hline$r_{i 10}$ & 14.00 & 744.8 & 207 & 753.22 & 8.42 & 89.0 \\
\hline$\mu_{11}$ & 14.17 & 742.6 & 190 & 753.21 & 10.60 & 113.0 \\
\hline$\eta_{4}$ & 16.10 & 745.9 & 151 & 753.23 & 7.33 & 77.4 \\
\hline$\mu_{4}$ & 16.50 & 742.6 & 189 & 753.40 & 10.80 & 113.2 \\
\hline
\end{tabular}

も嚴密に测定出來をから，後者の數值を舊海面の位置として其の後に受けた 運動を傾斜で表はして見ようと思ふ。

猶，第11 圖に示した值だけでは甚だ少小ので，更に之が補充として昭和 10 年 7 月に計测した量を第 3 表として揭げ，之を加へて運動を吟味した。殊 に第 1 段丘の汀線の值の大部分は此の新しい測高によつたものである。又第 4 段丘の值は，數が少い上に，前にも述べを通り $200 \mathrm{~m}$ の面の值と混同する 虞があるから，之を扱はずに，1，2，3 段丘のみで運動を調べる事にした。

第 11 圖は，以上の汀線の高さを其の位置に記大した本面圖である。實線 にして示した所は，現在其の位置に舊汀線の存在してょる所であり，點線に て示した所は現在舊汀線が存在せず，侵蝕にて消失した所を示す。之でも分 かる通り，第 2 段丘が最も連續性がよく，第 3 段丘之に次ぎ，第 1 段丘は須 崎牛島に於て最も良好な發達をなしてわる。

次に叙上 3 つの汀線の變動の傾向を察知する爲に，各汀線につき，相隣る 3 點を以て一本面をつくり，其の平面の傾科の具合を各點每に吟味して見 


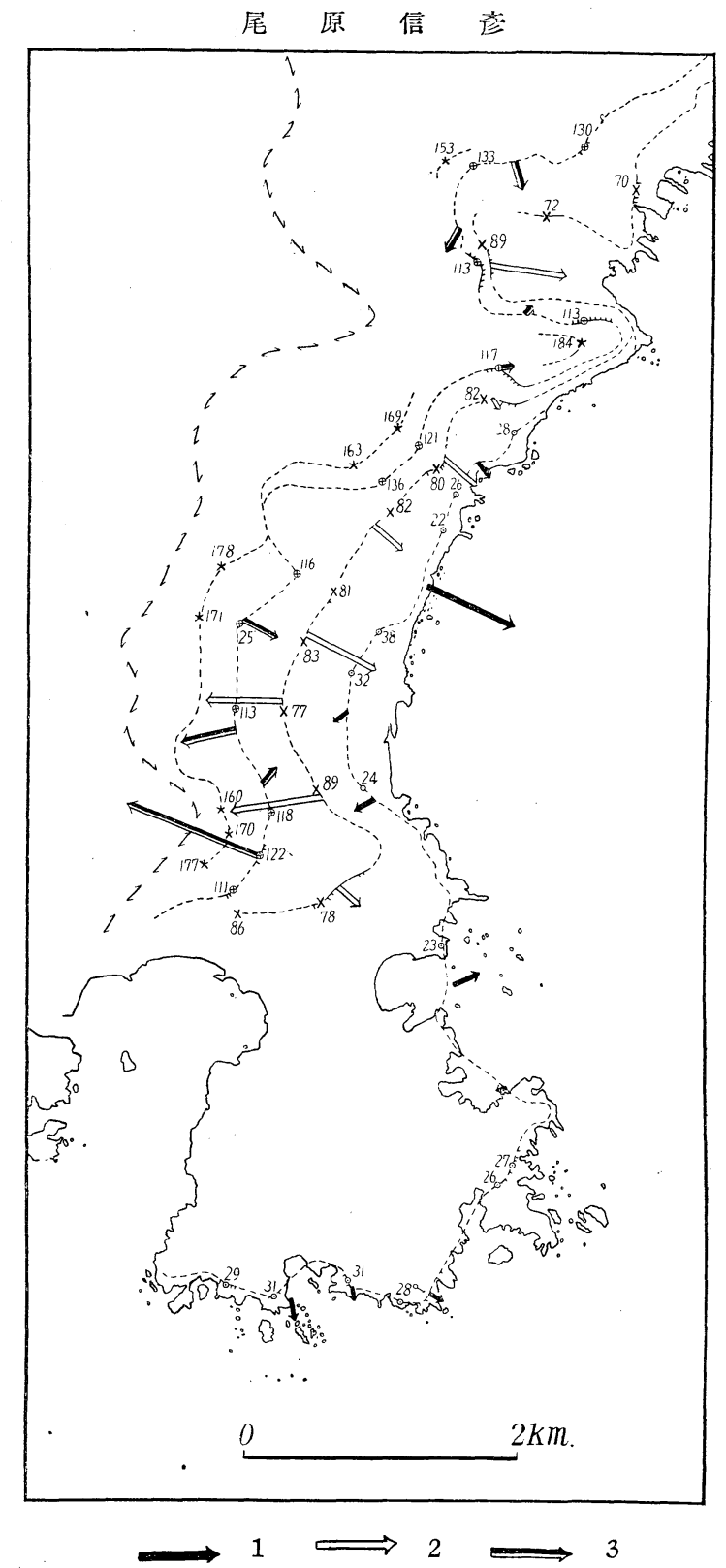

第 13 卷 
第 4 表 第 1 汀線の海拔高度と傾斜

\begin{tabular}{|c|c|c|c|c|}
\hline 第 1 汀線 & 慗高 & $\begin{array}{c}3 \text { 點ノ決定スル } \\
\text { 年 } \\
\text { 面 }\end{array}$ & $\begin{array}{l}\text { 海二對スル } \\
\text { 傾斜方向 }\end{array}$ & $\begin{array}{l}\text { 傾 斜 量 } \\
\operatorname{tg} \times 10^{2}\end{array}$ \\
\hline & $9^{m}$ & & & 1235 \\
\hline$\lambda_{1}$ & & $\lambda_{1} \lambda_{2} \lambda_{3}$ & 止 & 12.35 \\
\hline$\lambda_{2}$ & 34 & $\lambda_{2} \lambda_{3} \lambda_{4}$ & 正 & 2.49 \\
\hline$\lambda^{3}$ & 31 & $\lambda_{3} \lambda_{4} \lambda_{5}$ & 正 & 1.40 \\
\hline$\lambda_{4}$ & 31 & $\lambda_{4} \lambda_{5}{ }^{\lambda} 6$ & 正 & 0.81 \\
\hline$\lambda_{5}$ & 28 & $\lambda_{5} \lambda_{6} \lambda_{7}$ & 水本 & 0 \\
\hline$\lambda_{6}$ & 26 & $\lambda_{6}{ }^{\prime}{ }_{7} \lambda_{8}$ & 逆 & -0.96 \\
\hline$\lambda_{7}$ & 27 & $\lambda_{7} \lambda_{8} \lambda_{9}$ & 正 & 2.84 \\
\hline$\lambda_{8}$ & 23 & $\lambda_{8} \lambda_{9} \lambda_{10}$ & 逆 & -2.42 \\
\hline$\lambda_{9}$ & 24 & $\lambda_{9} \lambda_{10} \lambda_{11}$ & 逆 & -2.31 \\
\hline$\lambda_{10}$ & 32 & $\lambda_{11} \lambda_{12} \lambda^{1}$ & 正 & 14.03 \\
\hline$\lambda_{11}$ & 38 & $\lambda_{42} \lambda_{13}{ }^{\prime}{ }_{14}$ & 正 & 2.49 \\
\hline$\lambda_{12}$ & 22 & & & \\
\hline$\lambda_{13}$ & 28 & & & \\
\hline$\lambda_{14}$ & 28 & & & \\
\hline
\end{tabular}

第 5 表 第 2 汀線の海拔高度と傾斜

\begin{tabular}{|c|c|c|c|c|}
\hline 第 2 汀線 & 標高 & $\begin{array}{c}3 \text { 點ノ決定スル } \\
\text { 本 面 }\end{array}$ & $\begin{array}{l}\text { 海二對スル } \\
\text { 傾斜方向 }\end{array}$ & $\begin{array}{c}\text { 傾 科 量 } \\
\operatorname{tg} \times 10^{2}\end{array}$ \\
\hline$\eta_{1}$ & $86^{n}$ & $\eta_{1} \eta_{2} \eta_{3}$ & 正 & 3.5 \\
\hline$\eta_{2}$ & 78 & $\eta_{2} \eta_{3} \eta_{4}$ & 逆 & -12.4 \\
\hline$r_{3}$ & 89 & $r_{3} \eta_{4} \eta_{5}$ & 逆 & -9.7 \\
\hline$\eta_{4}$ & 77 & $\eta_{4} \eta_{5} \eta_{6}$ & 正 & 10.7 \\
\hline$\eta_{5}$ & 83 & $r_{5} r_{6} \eta_{7}$ & 正 & 一 \\
\hline$\eta_{6}$ & 81 & $\eta_{6} r_{7} \eta_{8}$ & 正 & 5.5 \\
\hline$\eta_{7}$ & 82 & $\eta_{7} \eta_{8} \eta_{9}$ & IE & 5.5 \\
\hline$\eta_{8}$ & 80 & $\eta_{8} \eta_{9} \eta_{10}$ & 正 & 8.4 \\
\hline$r_{9}$ & 82 & $\eta_{9} \eta_{10} \eta_{11}$ & 正 & 0.7 \\
\hline$\eta_{10}$ & 89 & & & \\
\hline$n_{11}$ & 72 & & & \\
\hline
\end{tabular}




\begin{tabular}{|c|c|c|c|c|}
\hline 第 3 汀線 & 標高 & $\begin{array}{c}3 \text { 點/決定 } \text { 本 } \\
\text { 面 }\end{array}$ & $\begin{array}{l}\text { 海二對スル } \\
\text { 傾斜方向 }\end{array}$ & $\begin{array}{c}\text { 傾斜 量 } \\
\operatorname{tg} \times 10^{2}\end{array}$ \\
\hline$\mu_{1}$ & ${ }_{111^{\mathrm{m}}}$ & $\mu_{1} \mu_{2}, \mu_{3}$ & 逆 & -18.0 \\
\hline$\mu_{2}$ & 122 & $\mu_{2} \mu_{3} \eta_{4}$ & 正 & 2.1 \\
\hline$\mu_{3}$ & 118 & $\mu_{3}, \mu_{4} \mu_{5}$ & 逆 & -6.7 \\
\hline$\mu_{4}$ & 113 & $\mu_{4} u_{5} / \cdot 6$ & 正 & 4.9 \\
\hline$\mu_{5}$ & 125 & $\mu_{5}{ }^{\prime \prime 6} u_{7}$ & 正 & 45.1 \\
\hline$\mu_{6}$ & 116 & $r_{s} u_{9} \mu_{10}$ & 正 & 0.6 \\
\hline$\mu_{7}$ & 136 & $\mu_{9} \mu_{10} u_{11}$ & 正 & 0.7 \\
\hline$\mu_{8}$ & 121 & $\mu_{10} \mu_{11} \mu_{12}$ & 逆 & -3.4 \\
\hline$\mu_{9}$ & 117 & $\mu_{11} \mu_{12} \mu_{13}$ & 正 & 3.4 \\
\hline$\mu_{10}$ & 113 & \multirow{4}{*}{\multicolumn{3}{|c|}{ 第 3 汀線の海拔高度 と傾斜 }} \\
\hline$\mu_{11}$ & 113 & & & \\
\hline$\mu_{12}$ & 133 & & & \\
\hline$\mu_{13}$ & 130 & & & \\
\hline
\end{tabular}

た。第 4 表㹥第 1 汀線につき第 5 表は第 2 汀線につき, 第 6 表は第 3 汀線に

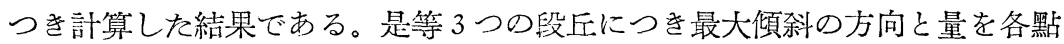
每に矢印にて示して第 11 圖に加へた。此回をを見れば, 原田附近にて逆傾斜の 運動が甚だしく集中してわる事がわかる。此處を除いては，皆大抵海に對し て正の傾科をしてるる。繩地山塊の附近は测點が甚だ少いので，稍、不明嘹 の感がないでもない。又第 1 段丘も須崎牛島の東岸に测點が少い。此邊は游 搶が激しく，適嫦を汀線の测定位置がなかつた。第 12 圖は今の結果を海面 に對して垂直な曲面（直立曲面）に投影したもので，縱軸には傾斜の量を， 橫軸には，水平の距離を取り相對應する山脚を 3 汀線とも一致せしめを。こ のグラフでもやはり原田附近に逆傾科が集中し，逆傾科する所は各汀線とも 共通してょる事が看取せられる。

次に第 11 圖を參照して，3段丘の 3 汀線を各幾つかの部分に分ち，各部分 の汀線の高度群が一平面をなす樣にし，その平面につき，3次元的に運動の 


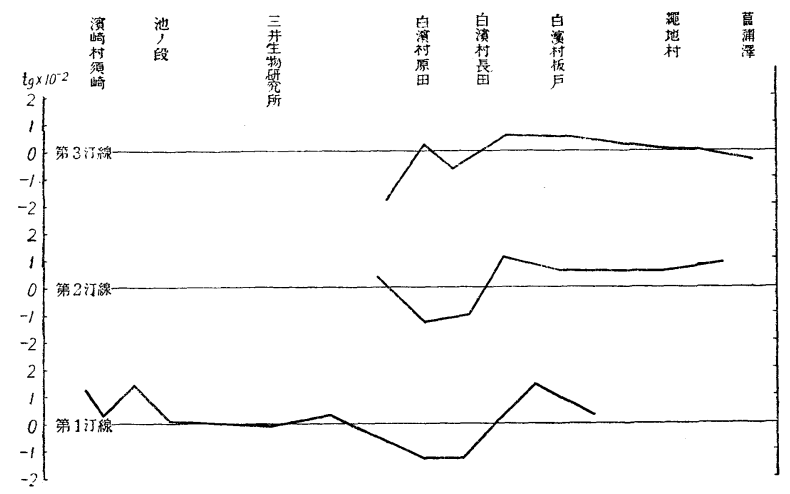

第 12 圖

量と變化形式を知らんとした。

郎ち，第 1 汀線については $\lambda_{1}-\lambda_{3}, \lambda_{3}-\lambda_{6}, \lambda_{7}-\lambda_{10}, \lambda_{10}-\lambda_{13}$ の 4 部分 に,第 2 汀線に就ては $\eta_{1}-\eta_{4}, \eta_{4}-\eta_{8}, \eta_{8}-\eta_{12}$ の3 部分に分かち, 第 3 汀線 は $\mu_{1}-\mu_{4}, \mu_{5}-\mu_{9}, \mu_{10}-\mu_{12}$ の3 部分に分かち, 各部分に於てあらゆる 2 點間の方位と傾斜（正切）を测定し，各群每に直交座標軸を作り，橫軸に方 位角 $\left(0^{\circ} \rightarrow 360^{\circ}\right)$ 縱軸に正切 $\left( \pm \operatorname{tg} \theta \times 10^{-2}\right)$ を取つて，上の测定值を記大 し，其值に出來るだけ近接する滑かな曲線を描いた。其の曲線が次の三角函 數によつて表はされるならぼ，叙上の各群は一本面上に在る事となり。且そ の式の常數によつて, 面の方位と傾斜が判明することとなる。郎ち

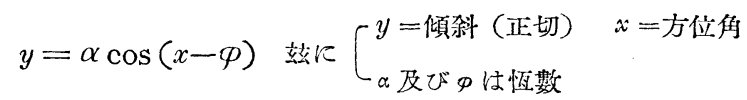

此の式は $y=-\alpha \cos \varphi=b$ とすれば $y=b+\alpha \cos x$ となり, Fourier の級數の主波のみあつて, 調和項のない場合に相當す。

さて，上の方法を實施するにあたり，曲線を出すには，選點法（Method (11) 今村學郎, 三野與吉 愛媛縣脏川下流地方の地波に就いて 地理學年報 1 (1933) p. 40 . 


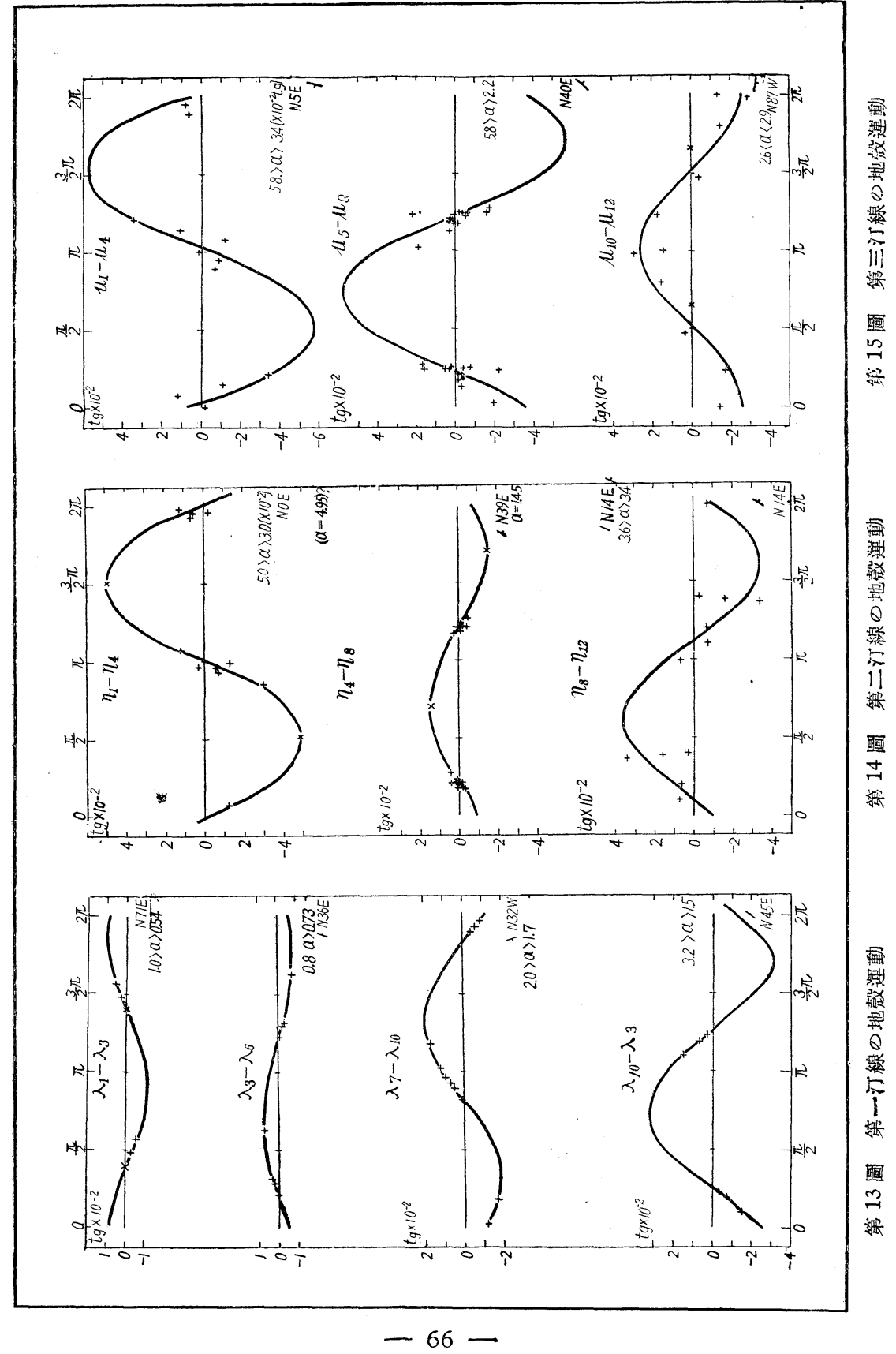


of selected points）に依つた。かくして得を各汀線の各群の點と曲線を圖示 すると，第 13 圖より第 15 圖迄となり，何れも餘弦曲線をなすか，少くもそ の傾向を有するので，1つのブロックと見なし得る。次に圖計算及び最小二 乘法によりその恒數を決定し，圖の傍にその實驗式を記し，且地質圖に於け る樣にブロックの方向，傾栋を示した。

この 11-12 圖及び 13-15 圖を見てすぐ氣のつく事は，第 2 第 3 汀線にお いて正逆相反する地域が一致してねる事である。郎ちグラフの山と谷とが上 (萬藏山 $\rightarrow$ 原田) と中(原田-一色) とで正反對を示し，中と下(繩地 $\rightarrow$ 葛浦澤） とでは，先づ一致してわる。この逆傾斜の地域は，第 1 汀線にも 1 万所(下) 觀取されるから，原田附近の地域は終始一貫して,か〉る逆傾科の運動の行は れてるた事がわかり，下田より白濱に出る舊街道の峠は，第IV章で述心゙た

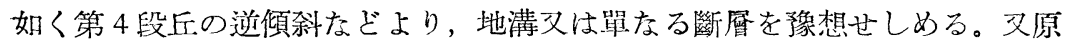
田部落の附近は, 白濱村の內で, 最も低本な地域で水田最も廣く, 溺谷の地 形を呈してねるので，長田，板戸，一色などの如く絕えず上昇の運動をして わた所に反し，原田附近のみ，上昇運動の中にも㮐、少量の下降があつて， をとへこれらの總和は正の運動であつても，他の地域と相對的には筫の運動 が認められるのである。かかる運動の地域的偏差は, 地塊運動として差支へ ないであらう。

須崎半島は，地質學的には單斜構造の臺地であつて，表面は海蝕により本 坦化されてるるが，第 1 汀線の運動では南端細間邊りを境として別くの運動 をなしてるる樣である。何れにしても傾科は極めて緩い。

原田から一色迄な, 各汀線が平行し, 且つ餘り水本的の擴りを有してねな いので，その傾斜量は稍、测定に困難を感じ，又誤差も他地域に比し，多か らうと思ふが，大體の傾向は察知せられた。長田と板戶との間に，未测量の 
山脚が 2 つ殘つて居り，これに附着する汀線は奥地に入り达んでわるから， 若しこの值が出たなら非常に確實となるであらう。

繩地以北は今の所測點が少く，稍、決定的な解釋を與ふるに躊躇するが，運 動は海に對して正であつて，原田一一色間と略、同樣である。運動量は稍。 少いかの如くに思はれる。此の地方は植被の關係から段丘地形は白濱附近よ り極めて明瞭である。第 2 段丘は河岸段丘となつて可成奧地迄も追跡できる。 唯本石山（繩地山塊）の地殼運動は多分偏倚がある筈であるが測點が僅少な. ので何とも言へない。

地殼運動量を各汀線每にまとめて表記すれば次の如くになる。

$$
\begin{array}{ll}
\text { 第 } 1 \text { 汀線 } & (1.0 \sim 3.2) \times 10^{-2} \\
\text { 第 } 2 \text { 汀線 } & (1.5 \sim 5.0) \times 10^{-2} \\
\text { 第 } 3 \text { 汀線 } & (2.9 \sim 5.8) \times 10^{-2}
\end{array}
$$

何れも $\left[10^{-2}\right]$ の程度として表はす事が出來，今村助敉授の地殼運動の分類 に於ける造山帶に該當する。上位に來る隆起汀線程, 其の量が大きく, 又テ クトニックの線が㐨想せられる樣な地域（例へぼ下田より白濱に出る舊街道 の峠：萬藏山塊の北部）は，かなり其運動量が大である事は注目に值する事 實として指摘しておきたい。

本研究に對し，今村助敉授には終始御指導を賜はり，又福井英一郎氏，吉 村講師には多忙中にも拘らず本報文の校閱を頂き，猶長津一郎氏には赤外線 寫真の貸與を賜つた。ここに特記して深謝の意を捧ぐ。(完)

（後記）第 2 圖の協力者に長津氏の名を謹んで追補す。

(12) Gakurô Imamura: Classification of crustal movements. The Bull. of the Eathquake Research Inst. Tokyo. XIII. (1935), part 1. p. 83. 